\title{
KARA OGRANICZENIA WOLNOŚCI Z ZASTOSOWANIEM DOZORU ELEKTRONICZNEGO - UTRACONA SZANSA NAPRAWY TEJ KARY W POLSKIM PRAWIE KARNYM
}

\section{WPROWADZENIE}

Ustawa z 20 lutego 2015 r. o zmianie ustawy - Kodeks karny i niektórych innych ustaw wprowadziła liczne zmiany w strukturze orzekania i wykonywania kar, m.in. reformując sposób wykonywania kary ograniczenia wolnościํ. Dzięki noweli lutowej pojawiła się możliwość orzeczenia obowiązku pozostawania $\mathrm{w}$ miejscu stałego pobytu lub w innym wyznaczonym miejscu z zastosowaniem systemu dozoru elektronicznego jako formy odbywania kary ograniczenia wolności. Reforma ta wkrótce została zahamowana, gdyż ustawa z 11 marca 2016 r. o zmianie ustawy - Kodeks karny i ustawy - Kodeks karny wykonawczy usunęła omawianą sposobność 2 .

W niniejszym artykule przedstawiono przyczyny wprowadzenia obowiązku pozostawania $\mathrm{w}$ miejscu stałego pobytu lub w innym wyznaczonym miejscu z zastosowaniem systemu dozoru elektronicznego jako jednej z form kary ograniczenia wolności, opierając się m.in. na materiałach legislacyjnych. Następnie dokonano oceny tej krótko obowiązującej zmiany w polskim prawie karnym, a także zaprezentowano przyczyny cofnięcia owej części reformy. Na zakończenie wysunięto uwagi de lege ferenda odnośnie do przywrócenia usuniętej nowela marcową omawianej formy kary ograniczenia wolności z pewnymi zmianami odnośnie do szczegółów dotyczących sposobu jej wykonywania.

\section{PRZYCZYNY ZMIAN W STRUKTURZE KARY OGRANICZENIA WOLNOŚCI WPROWADZONYCH NOWELĄ LUTOWĄ}

Uzasadnieniem noweli lutowej, będącej największą nowelizacją Kodeksu karnego od momentu jego uchwalenia, była - na co wskazuje Włodzimierz Wróbel - chęć

\footnotetext{
${ }^{1}$ Ustawa z 20 lutego 2015 r. o zmianie ustawy - Kodeks karny i niektórych innych ustaw, Dz. U. poz. 396 (dalej jako: nowela lutowa).

${ }^{2}$ Ustawa z 11 marca 2016 r. o zmianie ustawy - Kodeks karny i ustawy - Kodeks karny wykonawczy, Dz. U. poz. 428 (dalej jako: nowela marcowa).
} 
[...] zmiany struktury kar w kierunku poszerzenia zakresu stosowania kar wolnościowych oraz racjonalizacji orzekania kary pozbawienia wolności z warunkowym zawieszeniem jej wykonania, która od lat stanowiła podstawowy środek represji prawnokarnej ${ }^{3}$.

Głównym celem nowelizacji w świetle założeń projektu była zmiana polityki karnej przez stworzenie zasady preferencji orzekania kar nieizolacyjnych ${ }^{4}$. Jednym z zabiegów służących temu celowi było rozbudowanie i zwiększenie dolegliwości kary ograniczenia wolności ${ }^{5}$. Zgodnie bowiem ze słowami autorów uzasadnienia:

projektowane zmiany w art. 34 i 35 k.k. mają na celu zintensyfikowanie dolegliwości związanych z karą ograniczenia wolności oraz redukcję atrakcyjności reżimu probacyjnego związanego z orzekaniem kary pozbawienia wolności z warunkowym zawieszeniem jej wykonania. Kara ograniczenia wolności, obok grzywny, powinna stać się podstawową karą orzekaną za występki, których społeczna szkodliwość nie jest szczególnie wysoka [...]. Zasadniczej przebudowie podlega treść kary ograniczenia wolności, która staje się najbardziej elastyczną i możliwą do konkretyzowania a casu ad casum. Do jej zakresu przesuwa się pozbawienie wolności w trybie dozoru elektronicznego oraz inne obowiązki ograniczające konkretne wolności człowieka ${ }^{6}$.

Kara ograniczenia wolności miała stać się alternatywą dla kary pozbawienia wolności także wtedy, gdy kara pozbawienia wolności występowała jako jedyna sankcja karna dotycząca danego przestępstwa, a przez to „,...] dać ustawowy impuls do zróżnicowania opcji wyboru kary za określone kategorie przestępstw [...]” i stworzyć ,,[...] nowe ramy ustawowej polityki karnej, opartej w dużej mierze na kryteriach wolnościowych"7. Jednocześnie niezmienione pozostały normy sądowego wymiaru kary, a tym samym słusznie nie ograniczono autonomii sędziowskiej przy wyborze środka prawnokarnej reakcji ${ }^{8}$. Poszerzono wyłącznie granice, w których zgodnie z art. $53 \S 1$ k.k. in principio sąd ma wymierzyć karę według własnego uznania.

\section{FORMA WYKONYWANIA KARY OGRANICZENIA WOLNOŚCI Z ZASTOSOWANIEM DOZORU ELEKTRONICZNEGO}

Obowiązek pozostawania w miejscu stałego pobytu lub w innym wyznaczonym miejscu, z zastosowaniem systemu dozoru elektronicznego był zatem na mocy art. $34 \S 1$ a pkt 2 od 1 lipca 2015 r. do 15 kwietnia 2016 r. jedna z form

${ }^{3}$ W. Wróbel, Rozdział 1. Uwagi wstępne, w: idem (red.), Nowelizacja prawa karnego 2015. Komentarz, Kraków 2015, s. 27; ustawa z 6 czerwca 1997 r. - Kodeks karny, t.jedn.: Dz. U. 2016, poz. 1137 (dalej jako: k.k.).

${ }^{4}$ Uzasadnienie projektu ustawy z 20 lutego 2015 r. o zmianie ustawy - Kodeks karny, druk Sejmu VII kadencji nr 2393, cz. 1, http://orka.sejm.gov.pl/Druki7ka.nsf/0/39FD209B7AC6C45AC 1257CDE0042D631/\%24File/2393\%20cz\%201.pdf [dostęp: 30.11.2016].

${ }^{5}$ Ibidem.

${ }^{6}$ Ibidem.

${ }^{7} \mathrm{Na}$ mocy normy art. 37a k.k.; A. Grześkowiak, Model ustawowej polityki karnej na tle projektów zmian kodeksu karnego, w: D. Kala, I. Zgoliński (red.), Reforma prawa karnego materialnego i procesowego z 2015 roku. Wybrane zagadnienia, Warszawa 2015, s. 40.

8 Trzeba jednak pamiętać, na co zwraca uwagę A. Grześkowiak, że „sądowy wymiar kary, mimo że determinuje go zasada względnej swobody, powinien respektować założenia ustawowej polityki karnej” - ibidem, s. 34 . 
wykonywania kary ograniczenia wolności, która mogła zostać orzeczona do stałych, obligatoryjnych obowiązków tej kary, jakimi były zakaz samowolnej zmiany miejsca stałego pobytu i obowiązek udzielania wyjaśnień dotyczacych przebiegu kary (art. $34 \S 2$ k.k.) ${ }^{9}$. Orzeczenie tego obowiązku było możliwe w sposób samoistny lub kumulatywnie z trzema pozostałymi niestałymi, równorzędnymi i wybieranymi przez sąd elementami dolegliwości na ten sam okres bądź na inny, oczywiście w granicach wymierzonej przez sąd kary ograniczenia wolności (art. $34 \S 1$ b k.k.) ${ }^{10}$. Dzięki temu kara ograniczenia wolności mogła być, jak napisano w uzasadnieniu projektu:

[...] komponowana eklektycznie i uzyskać złożony charakter. Innymi słowy, według propozycji, możliwe będzie orzeczenie kary ograniczenia wolności na określony okres oraz skomponowanie jej treści przez orzeczenie jednego lub więcej obowiązków lub potrącenia określonych w projektowanym art. $34 \S 1 \mathrm{a}$. [...] Pozwoli to [...] na uzyskanie przez sąd możliwości skomponowania kary ograniczenia wolności o charakterze zmiennym w czasie ${ }^{11}$.

Ustawodawca zdefiniował obowiązek będący przedmiotem publikacji jako kontrolę zachowania skazanego za pomocą środków technicznych (art. 43b $\S 1$ k.k.w.) i ustanowił, że polega on w odniesieniu do kary ograniczenia wolności na dozorze stacjonarnym, czyli kontrolowaniu przebywania przez skazanego w określonych dniach tygodnia i godzinach we wskazanym przez sąd miejscu (art. 43b § 3 pkt 1 k.k.w.) ${ }^{12}$. Zgodnie z normą art. $35 \S 2$ k.k. sad miał określać czas wykonywania obowiązu, o którym mowa w art. 34 § 1a pkt 2 , uwzględniając warunki pracy skazanego oraz wymiar innych nałożonych obowiązków, przy czym nie mógł być on dłuższy niż 12 miesięcy oraz dłuższy niż 70 godzin w stosunku tygodniowym i 12 godzin w stosunku dziennym ${ }^{13}$.

Omawiany obowiązek polegał na rzeczywistym ograniczeniu wolności skazanego przez zobowiązanie go do przebywania w określonym przez sąd

${ }^{9}$ V. Konarska-Wrzosek, W kwestii nowego ksztattu kary ograniczenia wolności, w: W. Górowski et al. (red.), Zagadnienia teorii i nauczania prawa karnego. Kara łaczna, Warszawa 2013, s. 177. Wszystkie cytowane w tym rozdziale przepisy odnoszą się do stanu prawnego kreowanego przez nowelę lutową.

${ }^{10}$ J. Majewski, Komentarz do zmian 2015, Warszawa 2015, s. 55, 60 i 63 . Czyli z obowiązkiem wykonywania nieodpłatnej, kontrolowanej pracy na cele społeczne; niektórymi tzw. quasi-obowiązkami probacyjnymi (art. $72 \S 1$ pkt 4-7a k.k.) czy z potrąceniem od $10 \%$ do $25 \%$ wynagrodzenia za pracę w stosunku miesięcznym na cel społeczny wskazany przez sąd.

11 Cyt. za: ibidem, s. 64.

12 Ustawa z 6 czerwca 1997 r. - Kodeks karny wykonawczy, Dz. U. Nr 90, poz. 557 ze zm. (dalej jako: k.k.w.).

${ }^{13}$ Oznacza to, że kara ograniczenia wolności w tej formie mogła zostać orzeczona tylko na 12 miesięcy, a jeżeli jej wymiar wynosił więcej niż 12 miesięcy i zakładała nie tylko ten jeden obowiązek, to dozór elektroniczny musiał być stosowany krócej od pozostałych. „Czas wykonywania dozoru stacjonarnego jest niezależny od czasu wykonywania całej kary ograniczenia wolności” - T. Sroka, Rozdziat 4. Kara ograniczenia wolności, w: W. Wróbel (red.), op. cit., s. 119. Oczywiście w takim przypadku sąd musiał wyznaczyć skazanemu dodatkowy obowiąek, gdyż, jak słusznie zauważa J. Majewski (op. cit., s. 60): „orzeczenie kary ograniczenia wolności, która miałaby polegać wyłącznie na obowiązkach określonych w art. 34 § 2 pkt 1 i 3 (elementy stałe dolegliwości kary ograniczenia wolności), stanowiłoby rażące naruszenie art. $34 \S 1$ ””, gdyż „przesądza o tym użyty w początkowym fragmencie wspomnianego przepisu zwrot »kara ograniczenia wolności polega na«. 
miejscu i czasie ${ }^{14}$. Techniczny sposób wykonywania kary ograniczenia wolności z zastosowaniem dozoru elektronicznego tłumaczą Kamil Mamak i Dominik Zając:

Jest to możliwe dzięki zastosowaniu dwóch urządzeń technicznych, których działanie monitorowane jest w sposób zdalny, za pośrednictwem sieci GSM. Pierwszym z nich jest rejestrator stacjonarny w postaci niewielkiej skrzynki, montowanej w miejscu określonym orzeczeniem sądu. Drugi to nadajnik w postaci opaski zakładanej na kostkę bądź nadgarstek skazanego. Podmiot odpowiedzialny za techniczne aspekty funkcjonowania dozoru kalibruje zasięg rejestratora w ten sposób, by odnotowywał wszelkie przypadki zbliżenia doń nadajnika na odległość określoną przez sąd ${ }^{15}$.

Aby omawiany obowiązek mógł zostać orzeczony, konieczne było spełnienie dwóch warunków - technicznych (związanych z obsługą wspomnianych nadajników, obejmujące w szczególności liczbę czy zasięg dostępnych nadajników i rejestratorów oraz możliwości organizacyjne ich obsługi), a także rodzinnych i socjalno-bytowych ${ }^{16}$. $\mathrm{Na}$ warunki rodzinne i socjalno-bytowe składały się m.in. zgoda osób pełnoletnich mieszkajacych wspólnie ze sprawca, posiadanie przez niego miejsca, w którym mógłby stale przebywać (np. z dobrodziejstw tej formy nie mógł korzystać sprawca bezdomny czy nieposiadający mieszkania zasilanego energia elektryczna $)^{17}$. Zgoda osób zamieszkujących wraz ze sprawcą była konieczna ze względu na naruszenie sfery prywatności związane z zamieszczeniem urządzeń dozoru elektronicznego w ich lokalu ${ }^{18}$. Ustalenia w tym zakresie winny zapadać w postępowaniu wykonawczym. Oczywiście skazany zobowiązany był do nieprzerwanego noszenia nadajnika GSM oraz do należytego dbania (ochrony przed zniszczeniem) systemu technicznego dozoru elektronicznego czy umożliwiania do niego dostępu w celu naprawy ${ }^{19}$. Przepisy Kodeksu karnego wykonawczego przewidywały możliwość udzielenia zezwolenia skazanemu na opuszczenie miejsca wykonywania dozoru stacjonarnego na okres nieprzekraczajacy jednorazowo 7 dni czy przerwy w wykonaniu kary w tym systemie ${ }^{20}$.

${ }_{14}$ T. Sroka, op. cit., s. 113. Miejsce stałego pobytu zawarte w normie art. 34 § 1a pkt 2 należy rozumieć tak, jak wskazuje T. Sroka: „[...] miejsce zamieszkania w określonej miejscowości pod oznaczonym adresem z zamiarem stałego przebywania [...]" - ibidem, s. 114. Inaczej ujmując, jest to, jak sugeruje E. Żywucka-Kozłowska: „[...] miejsce, w którym skazany rzeczywiście przebywa” - eadem, Kara ograniczenia wolności po 1.7.2015 r., „Edukacja Prawnicza” 2016, nr 2, Legalis. Innym miejscem może być np. wynajęte przez skazanego mieszkanie - przykład za T. Sroką, op. cit., s. 115 . W stosunku tygodniowym 70 godzin to około 2,5 godziny dziennie, zakładając, że obowiązek sąd orzeka na każdy dzień. Zgodnie z normą art. 43k $§ 3$ k.k.w. przedziały czasu „ograniczenia wolności” w ciagu dnia nie mogły rozpoczynać się ani kończyć w godzinach między 23.00 a 5.00, chyba że było to uzasadnione wyjątkowymi, szczególnie uzasadnionymi okolicznościami związanymi z praca zawodową skazanego.

${ }^{15}$ K. Mamak, D. Zając, Dozór elektroniczny w świetle nowelizacji prawa karnego, w: S. Żółtek (red.), Z zagadnień prawa karnego, „Internetowy Przegląd Prawniczy TBSP UJ” 2015, nr 1, s. 131-132.

16 T. Sroka, op. cit., s. 117.

${ }^{17}$ Szczegóły w tym zakresie regulował przepis art. $43 \mathrm{~h} \S 1$ k.k.w.

18 T. Sroka, op. cit., s. 114.

19 Szczegółowe regulacje znajdowały się w art. $43 \mathrm{n} \S 1$ i 2 k.k.w.

${ }^{20}$ Art. 43p i 43q k.k.w. 


\section{PRZYCZYNY WYCOFANIA FORMY WYKONYWANIA KARY OGRANICZENIA WOLNOŚCI Z ZASTOSOWANIEM DOZORU ELEKTRONICZNEGO}

Z uzasadnienia noweli marcowej wynika, że zdaniem autorów tegoż projektu, dozór elektroniczny bardzo dobrze funkcjonował jako system wykonywania kary pozbawienia wolności na podstawie ustawy z 7 września 2007 r. o wykonywaniu kary pozbawienia wolności poza zakładem karnym w systemie dozoru elektronicznego ${ }^{21}$. Dzięki temu systemowi skazani na karę pozbawienia wolności zachowywali więź z rodziną i mieli możliwość wykonywania pracy zawodowej, toteż samodzielnie kontrolowali swoje zachowania i dostosowywali się do wymogów systemu ${ }^{22}$. Ponadto system ten umożliwiał, według projektodawcy, opuszczenie zakładu karnego, w którym pobyt nie zawsze przynosił pozytywne skutki resocjalizacyjne, i pozostawanie w pewnej formie kontroli w warunkach współuczestniczenia w życiu społeczeństwa ${ }^{23}$. Zdaniem zaś autorów projektu:

jednocześnie doświadczenia płynące z funkcjonowania systemu dozoru elektronicznego po dniu 1 lipca 2015 r., jako formy wykonywania kary ograniczenia wolności, wskazują na diametralny spadek liczby osób objętych tym systemem. Reforma wprowadzona ustawą z dnia 20 lutego 2015 r. o zmianie ustawy - Kodeks karny oraz niektórych innych ustaw (Dz.U. poz. 396) przeniosła uprawnienia dosięgania po system dozorów elektronicznych z sąów penitencjarnych na sądy orzekające w sprawie, tj. decyzja o stosowaniu SDE została przeniesiona z etapów wykonywania kary na moment orzekania o karze. Zmiana ta okazała się w praktyce wysoce nieefektywna i przyniosła drastyczny spadek orzeczeń o wykonywaniu kary w systemie dozoru elektronicznego. $\mathrm{Z}$ tego względu dalsze stosowanie systemu dozoru elektronicznego na potrzeby wykonywania kary ograniczenia wolności może doprowadzić do zmarginalizowania tej instytucji w sferze polityki karnej ${ }^{24}$.

Konkludując, ustawodawca słusznie zauważył, że „[...] wykonywanie dwóch różnych rodzajowo kar nie może następować w tej samej formie [...]”, dlatego zlikwidował możliwość wykonywania kary ograniczenia wolności z zastosowaniem dozoru elektronicznego i przywrócił dozór elektroniczny jako system odbywania kary pozbawienia wolności ${ }^{25}$.

Omawiana forma wykonywania kary ograniczenia wolności spotkała się także z krytyka, Macieja Małolepszego ${ }^{26}$, który uważał, że:

${ }^{21}$ Ustawa z 7 września 2007 r. o wykonywaniu kary pozbawienia wolności poza zakładem karnym w systemie dozoru elektronicznego, Dz. U. 2010, Nr 142, poz. 960 ze zm.; Uzasadnienie projektu ustawy z 11 marca 2016 r. o zmianie ustawy - Kodeks karny i ustawy - Kodeks karny wykonawczy, druk Sejmu VIII kadencji nr 218, http://orka.sejm.gov.pl/Druki8ka.nsf/0/1285BD 484E265537C1257F4E003531E0/\%24File/218.pdf [dostęp: 30.11.2016; dalej jako: Uzasadnienie projektu ustawy z 11 marca 2016 r.].

${ }^{22}$ Ibidem.

${ }^{23}$ Ibidem.

${ }^{24}$ Ibidem.

${ }^{25}$ Ibidem.

${ }^{26}$ M. Małolepszy, Rewolucyjna reforma polskiego systemu sankcji i jej możliwy wptyw na wymiar kar za przestepstwa przeciwko mieniu, http://www.zielona-gora.po.gov.pl/magazyn/upload/ lektury_elektroniczne/rewolucyjna-reforma-polskiego-systemu-sankcji-i-jej-mozliwy-wplyw-na-wymiar-kar-za-przestepstwa-przeciwko-mieniu.pdf [dostęp: 1.12.2016]. 
przeciwko zastosowaniu instytucji dozoru elektronicznego w ramach kary ograniczenia wolności przemawia przede wszystkim fakt, że dozór elektroniczny ze swej istoty wymaga zgody osoby dozorowanej. Oznacza to, że stosowanie tego środka nie jest możliwe bez jej zgodnego współdziałania. Jeżeli osoba dozorowana nie będzie skłonna pozostawać w miejscu stałego pobytu w wyznaczonym czasie, to nie istnieje możliwość wyegzekwowania tego obowiązku w drodze przymusu. Również względy prawne przemawiają za koniecznościa uzyskania zgody osoby dozorowanej - permanentna kontrola i nadzór głęboko ingeruja w sferę wolności osobistej skazanego oraz oddziałują [wyróż. - M.G.] na jego psychikę o wiele intensywniej niż w przypadku osadzenia w zakładzie karnym. Zarządzanie dozoru elektronicznego wbrew woli osoby kontrolowanej należałoby ocenić jako jawnie sprzeczne z godnością człowieka i jego prawem do samostanowienia. Stąd też zgoda skazanego jest nieodzowna ${ }^{27}$.

Pogląd ten jest zupełnie niezrozumiały z kilku powodów. Dlaczego autor zakładał konieczność uzyskania zgody skazanego na zastosowanie dozoru elektronicznego? Zgoda powinna być wymagana wyłącznie w odniesieniu do podjęcia terapii, ponieważ jest ona rodzajem świadczenia medycznego ${ }^{28}$. Obowiązek pozostawania $\mathrm{w}$ miejscu stałego pobytu lub w innym wyznaczonym miejscu, z zastosowaniem systemu dozoru elektronicznego był przecież forma kary ograniczenia wolności - kary, czyli dolegliwości wymierzanej sprawcy przez państwo z tytułu popełnienia przez niego przestępstwa. Podążając tokiem myślenia cytowanego autora, równie dobrze winno się wymagać zgody skazanego na karę pozbawienia wolności, gdyż zamknięcie w zakładzie karnym jest dużo dotkliwsze niż areszt domowy ${ }^{29}$. Być może cała idea kary ograniczenia wolności jest wadliwa, ponieważ z inna, pierwotną forma jej wykonywania - obowiązkiem nieodpłatnej, kontrolowanej pracy na cele społeczne wiązano, na co zwraca uwagę Elżbieta Hryniewicz:

[...] problem zgodności ujęcia pracy jako formy przymusu wiążącego się z sankcja karna z umowami międzynarodowymi zabraniajacymi pracy przymusowej lub obowiązkowej, których stroną jest Rzeczpospolita Polska ${ }^{30}$.

Ponadto forma ta również wymaga zgodnego współdziałania skazanego ${ }^{31}$. Nie rozstrzygając pierwszego z zarysowanych problemów, należy zaznaczyć, że nie jest możliwe odbycie kary ograniczenia wolności bez zgody skazanego w żad-

${ }^{27}$ Ibidem.

${ }^{28}$ Tak właśnie zakłada norma art. $74 \S 1$ k.k. w zw. z art. $35 \S 4$ k.k. w odniesieniu do quasi-obowiązków probacyjnych z przepisu art. $72 \S 1$ pkt 6 i 6 a k.k.

${ }^{29}$ Skoro stosowanie dozoru elektronicznego, zdaniem M. Małolepszego, „[...] ingeruje w sferę wolności osobistej skazanego oraz oddziałuje na jego psychikę o wiele intensywniej niż w przypadku osadzenia w zakładzie karnym [...], to dlaczego skazani tak chętnie wybierali właśnie ten system wykonywania kary pozbawienia wolności?” - idem, op. cit.; doświadczenia własne autora z pobytu w ZK w Lublincu 27 kwietnia 2016 r. na debacie poświęconej systemowi dozoru elektronicznego, http://www.sw.gov.pl/pl/okregowy-inspektorat-sluzby-wieziennej-katowice/zaklad-karny-lubliniec/ news,39797,debata-na-temat-systemu.html [dostęp: 1.12.2016].

${ }^{30}$ Szerzej na ten temat E. Hryniewicz, Obowiazek pracy na cele spoteczne jako element kary kryminalnej, „Ruch Prawniczy, Ekonomiczny i Socjologiczny” 75, 2013, z. 1, s. 111-113.

${ }^{31}$ Tak samo jak wykonanie każdej innej kary: grzywna wymaga uiszczenia kwoty pieniędzy, kara pozbawienia wolności - stawienia się skazanego do zakładu karnego, a następnie pozostawania w nim. 
nej z form, ponieważ może on uchylić się od jej wykonywania i sąd zarządza (lub może zarządzić) w takiej sytuacji wykonanie zastępczej kary pozbawienia wolności ${ }^{32}$. Ponadto, czy dozór elektroniczny zakłada w tym przypadku permanentną kontrolę? Otóż przewiduje on tylko obowiązek przebywania w miejscu stałego pobytu lub w innym miejscu wyznaczonym przez sąd maksymalnie w ciagu 70 godzin w stosunku tygodniowym i 12 godzin w stosunku dziennym, co - jak już zaznaczono - wynosi około 2,5 godziny dziennie w przypadku wykonywania tego obowiązku każdego dnia tygodnia ${ }^{33}$. Permanentny nadzór i kontrola charakterystyczne są dla kary pozbawienia wolności, na której orzeczenie sprawca nie musi wyrażać zgody.

\section{UWAGI DE LEGE LATA I DE LEGE FERENDA}

Na wstępie tej części rozważań trzeba odnieść się do stwierdzenia autorów noweli marcowej o wykonywaniu kary pozbawienia wolności poza zakładem karnym w systemie dozoru elektronicznego, który to - ich zdaniem - całkowicie spełnił pokładane w nim oczekiwania ${ }^{34}$. Stoi ono w sprzeczności z opinia przedstawicieli doktryny prawa penitencjarnego, którzy od samego początku wprowadzenia ustawy z 7 września 2007 r. o wykonywaniu kary pozbawienia wolności poza zakładem karnym w systemie dozoru elektronicznego odnosili się krytycznie do tej formy odbywania kary pozbawienia wolności ${ }^{35}$. Przedstawić należy kilka słusznych zarzutów, które wynikają z wad zastosowania systemu dozoru elektronicznego w odniesieniu do kary pozbawienia wolności, ale nie występują w stosunku do kary ograniczenia wolności wykonywanej w tej formie. Przede wszystkim w związku ze specyfiką systemu (skazany na karę pozbawienia wolności przebywa de facto na wolności), korzystać z jego dobrodziejstw mogą tylko sprawcy, którzy nie są wysoce zdemoralizowani i przez to nie będą stanowić zagrożenia dla chronionych dóbr społecznych, o czym świadczy przesłanka niskiego wymiaru orzeczonej kary pozbawienia wolności - nieprzekraczającej roku ${ }^{36}$. Przy pozostałej w Kodeksie karnym preferencji sankcji nieizolacyjnych oraz możliwości warunkowego umorzenia postępowania karnego i w nieco bardziej ograniczonym stopniu - zawieszenia wykonania kary pozbawienia wolności sprawcy o takiej pozytywnej prognozie kryminologicznej rzadko kiedy zostaną skazani na karę bezwzględnego pozbawienia

${ }^{32}$ Art. $65 \S 1$ k.k.w.: „Jeżeli skazany uchyla się od odbywania kary ograniczenia wolności lub nałożonych na niego obowiązków, sąd zarządza, a jeżeli uchyla się on od świadczenia pieniężnego lub obowiązków orzeczonych na podstawie art. 34 § Kodeksu karnego, sąd może zarządzić wykonanie zastępczej kary pozbawienia wolności”. Przepis ten brzmiał tak samo w okresie od 1 lipca 2015 r. do 15 kwietnia 2016 r.

${ }^{33}$ Nie wyklucza to, jak wskazuje T. Sroka, „[...] swobodnego kształtowania przez niego życia prywatnego poza wyznaczonymi godzinami” - idem, op. cit., s. 113.

${ }_{34}$ Uzasadnienie projektu ustawy z 11 marca $2016 \mathrm{r}$.

${ }^{35}$ Zob. np. M. Jankowski, S. Momot, Wykonywanie kary pozbawienia wolności w systemie dozoru elektronicznego (sprawozdanie z badania aktowego), „Prawo w Działaniu” 2015, nr 22, s. 191 i tamtejsze odesłania.

${ }^{36}$ Art. 43la $\S 1$ pkt 1 k.k.w.; M. Rusinek, Krytycznie o przyjętym ksztatcie dozoru elektronicznego, „Przegląd Więziennictwa Polskiego” 2008, nr 60, s. 56. 
wolności, nawet $\mathrm{w}$ tak niskim wymiarze ${ }^{37}$. O wiele bardziej zatem system ten sprawdzałby się w dalszym ciagu jako forma kary ograniczenia wolności, na którą powinni być skazywani sprawcy występków o nieco niższym stopniu społecznej szkodliwości.

Autorzy noweli marcowej podnieśli, że wykonywanie kary pozbawienia wolności w systemie dozoru elektronicznego miało pozytywne znaczenie w zakresie resocjalizacji i reintegracji społecznej skazanych ${ }^{38}$. Zdaniem Aleksandry Dziubińskiej pomimo 25 lat stosowania tego systemu na świecie

[...] nie można jednoznacznie ocenić skuteczności dozoru jako środka resocjalizującego, a badania wykazuja, że powrotność do przestępstw jest zbliżona do powrotności przy wykonywaniu kar izolacyjnych - ani czy - [...] faktycznie zmniejsza populację osadzonych i obniża koszty realizacji polityki kryminalnej $[\ldots]^{39}$.

Autorka zauważa też, że wykonywanie kary pozbawienia wolności w takim systemie akceptuja skazani, „[...] natomiast brak jest szerokiego poparcia społecznego" 40 .

Najważniejszy jednak zarzut, który trzeba podnieść przeciwko wykonywaniu kary pozbawienia wolności poza zakładem karnym w systemie dozoru elektronicznego, przedstawia Piotr Zawiejski, nazywając to „[...] fikcją pozbawienia wolności” ${ }^{41}$. Kara taka nie wypełnia w tym momencie należycie funkcji ochronnej na płaszczyźnie zabezpieczającej (izolacyjnej) oraz represyjnej ${ }^{42}$. System dozoru elektronicznego koresponduje natomiast doskonale z nazwa kary ograniczenia wolności, gdyż nie polega on na niczym innym jak właśnie na „ograniczeniu wolności”, a nie jej „pozbawieniu”43.

Nie jest słuszne dokonywanie negatywnej oceny funkcjonowania obowiąz$\mathrm{ku}$ pozostawania w miejscu stałego pobytu lub w innym wyznaczonym miejscu z zastosowaniem systemu dozoru elektronicznego jako formy wykonywania kary ograniczenia wolności po upływie zaledwie pół roku od jej wprowadzenia do systemu prawa karnego ${ }^{44}$. Cytowana wyżej A. Dziubińska zwraca uwagę, że trudno jednoznacznie ocenić skuteczność dozoru elektronicznego jako środka resocjalizującego po 25 latach jego stosowania na świecie, a nasz ustawodawca już po pół roku przesądził, że omawiany rodzaj dolegliwości

${ }^{37}$ Art. 37a, 58 § 1 oraz 59 k.k.

38 Uzasadnienie projektu ustawy z 11 marca $2016 \mathrm{r}$.

39 A. Dziubińska, Dwa lata obowiazywania przepisów ustawy o wykonywaniu kary pozbawienia wolności poza zakładem karnym w systemie dozoru elektronicznego-założenia $i$ ich realizacja, „Przegląd Więziennictwa Polskiego” 2012, nr 74-75, s. 193.

${ }^{40}$ Ibidem, s. 194.

${ }^{41}$ P. Zawiejski, Rozdziat XIII. Kary, w: T. Dukiet-Nagórska (red.), Prawo karne. Część ogólna, szczególna i wojskowa, Warszawa 2016, s. 245.

${ }^{42}$ K. Buchała, A. Zoll, Polskie prawo karne, Warszawa 1995, s. 11-13.

43 M. Szewczyk słusznie twierdzi, że „ta postać kary najbliższa jest znaczeniowo do nazwy «ograniczenie wolności» [...]” - eadem, Rozdział I § 3. Kara ograniczenia wolności, w: M. Melezini (red.), System prawa karnego, t. 6: Kary i inne środki reakcji prawnokarnej, Warszawa 2016 , s. 219.

44 Zmiana zaczęła obowiązywać 1 lipca 2015 r., a wycofujący ją projekt ustawy wpłyną do Marszałka Sejmu wraz z uzasadnieniem 26 stycznia 2016 r. 
kary ograniczenia wolności jest nieefektywny i może doprowadzić do zmarginalizowania dozoru elektronicznego w sferze polityki karnej ${ }^{45}$.

Nie powinno się bezkrytycznie podchodzić do instytucji każdej dziedziny prawa, a zwłaszcza tak mocno ingerującej w prawa i wolności człowieka, jaka jest prawo karne, dlatego również w karze ograniczenia wolności $\mathrm{w}$ postaci obowiązku pozostawania w miejscu stałego pobytu lub w innym wyznaczonym miejscu z zastosowaniem systemu dozoru elektronicznego trzeba dostrzec wady. Wynikają one z samej istoty dozoru elektronicznego i tak samo wpływają na nieatrakcyjność tegoż jako systemu wykonywania kary pozbawienia wolności. Otóż wiążą się one z warunkami technicznymi i rodzinnymi oraz socjalnobytowymi, które muszą zostać spełnione, aby dozór elektroniczny mógł zaistnieć. Inaczej mówiąc, nie jest on możliwy do zastosowania wobec wszystkich skazanych na karę ograniczenia wolności ${ }^{46}$. Konieczne jest wzmocnienie zasięgu sygnału GSM, ponieważ w wielu miejscowościach (i to nie tylko małych wioskach, ale i przykładowo w centrum Krakowa) stosunkowo niedawno nie było możliwe stosowanie tego systemu właśnie z powodu zbyt słabego sygnału ${ }^{47}$. Jakakolwiek kara wykonywana z wykorzystaniem dozoru elektronicznego nosi w sobie również element piętnujący skazanego, wiążący się z koniecznością noszenia opaski połączonej bezprzewodowo z nadajnikiem, co niewątpliwie ze względów humanitarnych nie jest jej zaletą ${ }^{48}$.

Wadą omawianej formy jest również fakt, że przygotowanie warunków umożliwiajacych wykonanie kary w systemie dozoru elektronicznego może trwać nawet kilka miesięcy i przyjmując jedność kary ograniczenia wolności i tym samym moment początkowy odbywania całej kary od dnia rozpoczęcia pierwszej z orzeczonych form (np. nieodpłatnej, kontrolowanej pracy na cele społeczne), może się okazać, że w rzeczywistości obowiąek pozostawania w miejscu stałego pobytu lub w innym wyznaczonym miejscu, z zastosowaniem systemu dozoru elektronicznego będzie wykonywany krócej niż pozostałą (pozostałe) formę nawet wtedy, gdy zostaną one orzeczone na ten sam okres $^{49}$. Tę lukę w prawie można rozwiązać w prosty sposób: przez dodanie

${ }^{45}$ A. Dziubińska, op. cit., s. 193; Uzasadnienie projektu ustawy z 11 marca 2016 r.

${ }^{46} \mathrm{~Np}$. nie można go zastosować w przypadku braku zgody osoby mieszkającej wraz ze sprawcą czy niedostatkach lokalowych skazanego (bezdomność, brak energii elektrycznej). Niemniej nie jest to wada drastycznie wpływająca na negatywną ocenę omawianej formy - również i kara ograniczenia wolności w postaci nieodpłatnej, kontrolowanej pracy na cele społeczne nie może być orzeczona wobec osoby, która tej pracy nie jest w stanie wykonywać. Tak samo nie orzeka się kary grzywny w stosunku do sprawcy nieposiadającego żadnych możliwości jej spłaty czy nie można potrącać wynagrodzenie bezrobotnego.

${ }^{47}$ Doświadczenia własne autora z pobytu w ZK w Lublincu 27.4.2016 r. na debacie poświęconej systemowi dozoru elektronicznego - http://www.sw.gov.pl/pl/okregowy-inspektorat-sluzby-wieziennej-katowice/zaklad-karny-lubliniec/news,39797, debata-na-temat-systemu.html [dostęp: 1.12.2016].

48 Ibidem.

${ }^{49}$ O konieczności przyjęcia koncepcji jedności kary ograniczenia wolności pisze T. Sroka, Koncepcja jedności kary ograniczenia wolności w nowym modelu tej kary po nowelizacji $z 20$ lutego 2015 r., „Palestra” 2015, nr 7-8, s. 55. Pogląd ten trzeba całkowicie zaakceptować. 
przepisu nakazującego w przypadku orzeczenia kilku form odbywania kary ograniczenia wolności rozpoczęcie ich wykonywania jednocześnie ${ }^{50}$.

Przechodząc z uwag de lege lata do wniosków de lege ferenda, należy krytycznie odnieść się do zmian wprowadzonych przez nowelę marcowa, polegających na zlikwidowaniu możliwości zastosowania dozoru elektronicznego jako jednej z form wykonywania kary ograniczenia wolności i przywrócenia tej instytucji do zakresu prawa penitencjarnego, co uczyniło z niej ponownie system odbywania kary pozbawienia wolności. Abstrahując od samego powzięcia decyzji dotyczącej marcowej nowelizacji, stanowczo za szybkiej, bez czasu na adaptację reformy kary ograniczenia wolności w polskim porządku prawnym, może być ona oceniona niekorzystnie, a tym samym zahamować rozpoczęte nowelą lutową zmiany w systemie orzekania i wykonywania kar. Od lipca $2015 \mathrm{r}$. to grzywna miała stać się „[...] głównym środkiem reakcji karnej w odniesieniu do »drobnej« i »średniej« przestępczości”, a „uzupełniać grzywnę w tej funkcji miała kara ograniczenia wolności" ${ }^{51}$. Ustawodawca widział w karze ograniczenia wolności nie tylko, jak twierdzi Jarosław Majewski, równorzędną alternatywę dla kary grzywny, ale przede wszystkim dla kary pozbawienia wolności, aby dzięki normie art. 37a k.k. mogła być orzekana wobec większej liczby występków, w tym także posiadających nieco wyższy abstrakcyjny stopień społecznej szkodliwości ${ }^{52}$. Niestety z powodu cofnięcia możliwości zastosowania dozoru elektronicznego jako jednej z form wykonywania kary ograniczenia wolności atrakcyjność tej sankcji znacznie spadła, co może spowolnić lub nawet zatrzymać postęp $\mathrm{w}$ preferowaniu kar nieizolacyjnych $\mathrm{w}$ stosunku do sprawców należących do drobnej i średniej przestępczości.

Oczywiście należy pamiętać, że dokonane przez ustawodawcę oraz postulowane przez autora nowelizacje w katalogu kar i w sposobie ich orzekania nie spowodowały ani nie spowoduja zmian w normach sądowego wymiaru kary. Oznacza to, że nadal struktura orzekanych kar zależna jest od konkretnych przypadków rozpatrywanych przez sąd. Żadna zmiana dokonana w tym zakresie nie wpływa na zakres autonomii sądowej przy wymiarze kary, jak również nie ograniczy możliwości orzeczenia kary pozbawienia wolności z warunkowym zawieszeniem jej wykonania, jeżeli zdaniem sądu w konkretnym przypadku to właśnie ta kara połączona z obowiązkiem probacyjnym spełni należycie funkcje względem skazanego oraz społeczeństwa. Zadaniem sądu jest przecież wymierzenie kary według swojego uznania w granicach przewidzianych przez ustawę, a omawiane rozbudowanie kary ograniczenia wolności może jedynie korzystniej wpłynąć na realizację zasady priorytetu kar nieizolacyjnych (art. $58 \S 1$ k.k. z zw. z art. 37a k.k.) przez poszerzenie granic, w ramach których sąd może orzekaćs3.

\footnotetext{
${ }^{50} \mathrm{~Np}$. zaczyna się potrącać skazanemu wynagrodzenie za pracę na cele społeczne dopiero od momentu rozpoczęcia przez niego odbywania obowiązku pozostawania $\mathrm{w}$ miejscu stałego pobytu lub w innym wyznaczonym miejscu, z zastosowaniem systemu dozoru elektronicznego.

${ }^{51}$ J. Majewski, op. cit., s. 49.

52 Ibidem.

${ }^{53}$ O. Sitarz, Rozdziat XVII. Wymiar kary i środków karnych, w: T. Dukiet-Nagórska (red.), op. cit., s. 303-304.
} 
Konkludując, należy wysunąć postulat de lege ferenda, aby ustawodawca przywrócił usunięte nowelą marcową przepisy, a obowiązek pozostawania $\mathrm{w}$ miejscu stałego pobytu lub $\mathrm{w}$ innym wyznaczonym miejscu z zastosowaniem systemu dozoru elektronicznego stał się ponownie jedną z możliwych dolegliwości kary ograniczenia wolności. Dzięki temu kara ta znów może zyskać rzeczywisty wydźwięk jako „ograniczenie wolności”, pozbawienie skazanego możliwości poruszania się w określonym, zasadniczo krótkim przedziale czasu. Zbliży to ja do kary aresztu, przewidzianej w art. 40 Kodeksu karnego z 1932 r., która - jak przypomina Elżbieta Żywucka-Kozłowska - polegała na zakazie opuszczania przez skazanego swojego mieszkania oraz przyjmowania gości bez zezwolenia władzy zarządzającej wykonanie kary ${ }^{54}$. Powrót systemu dozoru elektronicznego do kary ograniczenia wolności zwiększy jej dolegliwość, a tym samym ją uelastyczni. Dzięki temu będzie można orzec ją jako sankcję w większej liczbie przypadków. Dla przykładu, sprawca przestępstw kradzieży, oszustwa (w typach podstawowych zagrożonych odpowiednio kara pozbawienia wolności od 3 miesięcy do lat 5 oraz od 6 miesięcy do lat 8) czy prowadzenia pojazdu mechanicznego w stanie nietrzeźwości w warunkach „recydywy” (art. 178a $\S 4$ k.k., zagrożone kara pozbawienia wolności od 3 miesięcy do lat 5), które cechują się znacznym abstrakcyjnym stopniem społecznej szkodliwości, może dzięki normie art. 37a k.k. podlegać karze ograniczenia wolności zamiast karze pozbawienia wolności. Jeżeli sąd zdecyduje się w takich przypadkach orzec karę ograniczenia wolności, to jej dolegliwość winna m.in. uwzględniać stopień społecznej szkodliwości czynu oraz spełniać cele zapobiegawcze ${ }^{55}$. Kara taka musi się zatem cechować dostateczną surowościa, aby być dla sądu atrakcyjną alternatywa wobec kary pozbawienia wolności ${ }^{56}$. Wydaje się, że wymierzenie kary ograniczenia wolności $\mathrm{w}$ formie obowiązku pozostawania w miejscu stałego pobytu lub w innym wyznaczonym miejscu, z zastosowaniem systemu dozoru elektronicznego, zarówno samoistnego, czy w szczególności połączonego z pozostałymi formami, spełniałoby w takich przypadkach funkcję ochronna, realizowana zarówno na płaszczý́nie prewencyjnej, represyjnej, jak i zabezpieczającej ${ }^{57}$. Racjonalny wydaje się osąd, że kara ograniczenia wolności zawierająca jako jedną z dolegliwości omawiany obowiązek byłaby odbierana pozytywniej nie tylko przez sądy, ale i przez społeczeństwo i tym samym skuteczniej realizowała funkcję ochronną na płaszczyźnie prewencyjnej (zwłaszcza generalnej negatywnej) $)^{58}$.

Pożądane przywrócenie obowiązku pozostawania w miejscu stałego pobytu lub w innym wyznaczonym miejscu, z zastosowaniem systemu dozoru elektronicznego jako formy wykonywania kary ograniczenia wolności, nie powinno odbyć się bez pewnych zmian, które nie występowały w noweli lutowej. Przede wszystkim należy dodać przepis, o którym była mowa powyżej, nakazujący

${ }^{54}$ E. Żywucka-Kozłowska, op. cit., i tamtejsze odesłania; rozporządzenie Prezydenta RP z 11 lipca 1932 r. - Kodeks karny, Dz. U. 60, poz. 571 ze zm.

${ }_{55}$ Co wynika z dyrektyw ogólnych wymiaru kary z art. 53 § 1 k.k.

56 V. Konarska-Wrzosek, op. cit., s. 179.

${ }_{57}$ Funkcja ochronna rozumiana tak jak u K. Buchały i A. Zolla, op. cit., s. 11-13.

${ }^{58}$ Co sugeruje V. Konarska-Wrzosek, op. cit., s. 179. 
w przypadku orzeczenia kilku form odbywania kary ograniczenia wolności, rozpoczęcie ich wykonywania jednocześnie. Dodatkowo warto rozważyć wydłużenie możliwości odbywania tego obowiązku do 2 lat, czyli poprzez cały okres, na jaki może zostać orzeczona przedmiotowa kara, co spowodowałoby pełniejsze wykorzystanie owej formy i wpłynęło korzystniej na realizację funkcji ochronnej sankcji na płaszczyźnie represyjnej i prewencyjnej. Zbędne jest natomiast przywracanie art. $43 \mathrm{k} \S 3 \mathrm{k} . \mathrm{k} . \mathrm{w}$. w brzmieniu ustalonym przez nowelę lutowa, ponieważ słuszne wydaje się pozostawienie sądowi sposobności orzeczenia obowiązku pozostawania $\mathrm{w}$ miejscu stałego pobytu lub $\mathrm{w}$ innym wyznaczonym miejscu, z zastosowaniem systemu dozoru elektronicznego również w godzinach nocnych (od godz. 23.00 do 5.00), przykładowo, gdy skazany właśnie w tym czasie popełnił przestępstwo ${ }^{59}$.

\section{PODSUMOWANIE}

Kara ograniczenia wolności z zastosowaniem dozoru elektronicznego była szansą na naprawę tej kary w polskim prawie karnym, nowela marcowa sprawiła zaś, że została ona utracona. Należy mieć nadzieję, że jest to strata tymczasowa, gdyż kara ograniczenia wolności z możliwością orzeczenia obowiązku pozostawania $\mathrm{w}$ miejscu stałego pobytu lub w innym wyznaczonym miejscu $\mathrm{z}$ zastosowaniem systemu dozoru elektronicznego w postaci regulowanej przepisami noweli lutowej, uzupełniona o uwagi wyrażone powyżej we wnioskach de lege ferenda mogłaby być dobrą alternatywą zarówno dla kar pozbawienia wolności przewidzianych za występki zaliczajace się do drobnej i średniej przestępczości, jak i dla kary grzywny, a tym samym prowadzić do lepszej realizacji zasady priorytetu kar nieizolacyjnych ${ }^{60}$. W zależności od konkretnego czynu oraz sprawcy kara ograniczenia wolności w postulowanej postaci ograniczałaby - pojedynczo lub wszystkie razem, elementy składowe wolności człowieka -

[...] wolność wyboru miejsca pobytu, wolność wyboru pracy i miejsca jej wykonywania, wolność w zakresie organizacji wolnego czasu (ewentualnie wolność w zakresie dysponowania wynagrodzeniem za prace [...] - a tym samym - [...] ograniczałaby [...] prawo skazanego do autodeterminacji swoich zachowań ${ }^{61}$.

Dzięki temu mogłaby spełnić wszystkie wszystkie funkcje przypisywane karze przez doktrynę prawa karnego i być pozytywnie ocenianym oraz chętnie stosowanym przez sądy środkiem prawnokarnej reakcji.

mgr Michat Grudecki

Uniwersytet Ślaski w Katowicach

m.grudecki@us.edu.pl

\footnotetext{
${ }_{59} \mathrm{~Np}$. złodziej okradający nocą sklepy; młody kierowca, który w stanie nietrzeźwości wracał samochodem w nocy z dyskoteki.

${ }^{60}$ Uwzględniając pozytywnie ocenianą normę art. 37a k.k.

${ }^{61}$ R. Giętkowski, Komentarz do art. 34, w: R. Stefański (red.), Kodeks karny. Komentarz, Warszawa 2015, s. 290.
} 


\section{A RESTRICTION OF LIBERTY ORDER MONITORED ELECTRONICALLY - A LOST CHANCE IN POLISH CRIMINAL LAW}

\section{Sum mary}

The Act on the Amendments to the Penal Code and some other Acts of 20 February 2015 modified many regulations concerning the structure and the way of executing penalties, including the restriction of liberty. In this paper, the reasons for the implementation of an order requiring a person to remain within their home or stay at the restriction place, being electronically monitored, are presented and assessed. This is followed by the assessment of the provisions of the Executive Penal Code governing this form of punishment, which was briefly available under Polish criminal law. The author presents the reasons why a restriction of liberty order had been introduced in the first place and then abolished by the Act Amending the Executive Penal Code of 11 March 2016 and offers his own explanation of this. He also examines whether the amendment of February 2015 was a right decision and presents his own views, concluding with some de lege ferenda points regarding the possibility of re-introducing the order of the restriction of liability, but with certain amendments pertaining to the detailed execution of this order. 
